Article

\title{
Chemical Composition, Insecticidal, Persistence and Detoxification Enzyme Inhibition Activities of Essential Oil of Artemisia maritima against the Pulse Beetle
}

\author{
Nandita Chauhan ${ }^{1}$, Urvashi Kashyap ${ }^{1,2} \mathbb{D}$, Shudh Kirti Dolma ${ }^{1,2} \mathbb{D}$ and Sajjalavarahalli G. Eswara Reddy ${ }^{1,2, *(\mathbb{D})}$ \\ 1 Entomology Laboratory, Agrotechnology Division, CSIR-Institute of Himalayan Bioresource Technology, \\ Palampur 176061, India; nanditachauhan796@gmail.com (N.C.); kashurvi5991@gmail.com (U.K.); \\ skdolma@gmail.com (S.K.D.) \\ 2 Academy of Scientific and Innovative Research (AcSIR), Ghaziabad 201002, India \\ * Correspondence: ereddy@ihbt.res.in or ereddy2001@yahoo.com
}

Citation: Chauhan, N.; Kashyap, U.; Dolma, S.K.; Reddy, S.G.E. Chemical Composition, Insecticidal, Persistence and Detoxification Enzyme Inhibition Activities of Essential Oil of Artemisia maritima against the Pulse Beetle. Molecules 2022, 27, 1547. https:// doi.org/10.3390/molecules27051547

Academic Editor: Mihai Brebu

Received: 25 January 2022

Accepted: 19 February 2022

Published: 25 February 2022

Publisher's Note: MDPI stays neutral with regard to jurisdictional claims in published maps and institutional affiliations.

Copyright: (c) 2022 by the authors. Licensee MDPI, Basel, Switzerland. This article is an open access article distributed under the terms and conditions of the Creative Commons Attribution (CC BY) license (https:// creativecommons.org/licenses/by/ $4.0 /)$.

\begin{abstract}
Pulse beetle is the major pests of pulses that cause significant loss to grains leads to unfit for consumption and marketing. Indiscriminate use of synthetic pesticides for the control of pulse beetle (Callosobruchus chinensis and Callosobruchus maculatus) led to insect resistance, pesticide residues on grains which affect consumer's health and environment. Essential oils (EOs) are good alternatives to synthetics due to their safety to the environment and consumers' health. The main objective of the present study was to explore the chemical composition, fumigant, repellency, ovipositional deterrence, persistence, and detoxification enzyme inhibition of Artemisia maritima essential oil against pulse beetle. Results showed that primary components of the $\mathrm{EO}$ were 1,8-Cineole and bornyl acetate. EO showed promising fumigant toxicity to C. chinensis and C. maculatus $\left(\mathrm{LC}_{50}=1.17\right.$ and $0.56 \mathrm{mg} / \mathrm{L}$, respectively) after $48 \mathrm{~h}$. In the repellent assay, EO at $8 \mathrm{mg} / \mathrm{L}$ showed $92-96 \%$ repellence after $1 \mathrm{~h}$. In ovipositional deterrence assay, EO showed more ovipositional deterrence against C. chinensis $\left(\mathrm{OD}_{50}=3.30 \mathrm{mg} / \mathrm{L}\right)$ than C. maculatus $\left(\mathrm{OD}_{50}=4.01 \mathrm{mg} / \mathrm{L}\right)$. Higher concentrations of oil ( 8 and $6 \mathrm{mg} / \mathrm{L}$ ) in C. maculatus showed significant inhibition of the glutathione-S-transferase enzyme (7.14 and $5.61 \mathrm{n} \mathrm{mol} / \mathrm{min} / \mathrm{mL}$, respectively).
\end{abstract}

Keywords: fumigant; persistence; repellence; ovipositional; AChE; GST

\section{Introduction}

Infestation of bruchids and lepidopterans pests causes significant damage to grains and their products in storage. More than 500 species of the stored grains and cereal products are often infested by more than 600 species of coleopterans [1] causing 20-30\% loss, affecting nutritional value and germination [2]. Bruchids, Callosobruchus chinensis and C. maculatus (Coleoptera: Bruchidae), are primary pests of pulses and cause $50 \%$ loss in storage after three to four months [3,4]. The grub's bore into grains, feed internal contents, affecting nutritional quality [5]. In severe infestation, seeds become completely hollow and unsuitable for marketing [6]. The control of stored grain pests generally depends on synthetic insecticides, including fumigants [5,7]. The use of synthetic insecticides resulted in several negative effects in the environment, natural enemies, human health, and resistance development in insects. Now the focus is shifted to search of potent insecticide from natural origin. Plant essential oils (EOs), its monoterpenoids and sesquiterpenoids are known to possess significant insecticidal activities against stored grain pests [8-10] The EOs are extracted from different parts (leaves/flowers/seeds/bark) of aromatic and medicinal plants. Nearly $10 \%$ of EOs used in aromatic, flavor and fragrance industries [11].

Sea wormwood (Artemisia maritima L.) is an aromatic perennial herb distributed in the western Himalayas (Kashmir, Himachal Pradesh, and Uttarakhand [12]. Essential 
oil is used for antibacterial, antifungal, antispasmodic, antimalarial, and bronchodilatory activities [12-14]. Presently, EOs and their secondary metabolites of Artemisia spp. are extensively used in folk/modern medicine, cosmetics, food, forage, and pharmaceuticals for the control of malaria, hepatitis, cancer, inflammation, and infections caused by fungi/bacteria/viruses [14-17] and treatment of COVID-19 [18]. The EO from A. annua, A. judaica, A. dracunculus, A. santonicum, A. spicigera, A. vulgaris, A. scoparia, and A. sieberi showed contact, fumigant, repellent, and ovipositional activities against pulse beetle [19-24] and other pests $[16,25,26]$. Insecticidal activities of A. maritima oil are reported in some insect pests but no report on pulse beetle. In this study, the main objective of the investigation was to evaluate the A. maritima oil for fumigant, repellent, ovipositional, persistent activity, and detoxification enzyme inhibition against pulse beetle.

\section{Results}

\subsection{Chemical Composition of A. maritima Oil}

A total of 14 compounds-accounting for $98.51 \%$ of A. maritima were identified by GC and GC-MS. The oil was composed of $28.11 \%$ monoterpene hydrocarbons, $45.73 \%$ oxygenated monoterpene fraction, and $2.42 \%$ oxygenated sesquiterpene. The major components of the oil were 1,8 -cineole $(41 \%)$ and bornyl acetate $(18.10 \%)$ followed by myrcene $(9.59 \%)$, sabinene $(6.42 \%)$, camphene $(3.74 \%)$, and $\beta$-phellandrene $(3.68 \%)$. Other components included terpinolene, germacrene-D, santolina triene, chrysanthenyl acetate (Table 1).

Table 1. Chemical composition of essential oil of A. maritima.

\begin{tabular}{|c|c|c|c|c|c|}
\hline Sr. No. & Name & $\mathbf{R I}^{\mathbf{a}}$ & $\mathbf{R I}^{\mathbf{b}}$ & Area $(\%)$ & $\begin{array}{c}\text { Mode of } \\
\text { Identification }\end{array}$ \\
\hline 1 & Santolina triene & 908 & 903 & 2.18 & MS, RI \\
\hline 2 & Camphene & 953 & 954 & 3.74 & MS, RI \\
\hline 3 & Sabinene & 976 & 975 & 6.42 & MS, RI \\
\hline 4 & Myrcene & 991 & 990 & 9.59 & MS, RI \\
\hline 5 & $\beta$-phellandrene & 1031 & 1022 & 3.68 & MS, RI \\
\hline 6 & 1,8-cineole & 1033 & 1028 & 41.14 & MS, RI \\
\hline 7 & Terpinolene & 1088 & 1090 & 2.50 & MS, RI \\
\hline 8 & trans-thujone & 1112 & 1109 & 2.61 & MS, RI \\
\hline 9 & Chrysanthenyl acetate & 1262 & 1259 & 0.96 & MS, RI \\
\hline 10 & Bornyl acetate & 1284 & 1287 & 18.10 & MS, RI \\
\hline 11 & Sabinyl acetate & 1291 & 1289 & 1.16 & MS, RI \\
\hline 12 & Isobornylpropanate & 1381 & 1378 & 2.03 & MS, RI \\
\hline 13 & Germacrene-D & 1480 & 1484 & 2.42 & MS, RI \\
\hline 14 & Isobornyl 2-Methyl butyrate & 1520 & 1510 & 1.98 & MS, RI \\
\hline \multirow[t]{6}{*}{15} & Unknown & - & - & 1.50 & MS, RI \\
\hline & Total & & & 98.51 & \\
\hline & Monoterpene hydrocarbons * & & & 28.11 & \\
\hline & Oxygenated monoterpene * & & & 45.73 & \\
\hline & Sesquiterpene hydrocarbons * & & & 2.42 & \\
\hline & Oxygenated sesquiterpene * & & & 0.0 & \\
\hline
\end{tabular}

${ }^{a}$ Retention index value of compounds in the literature (Adams 2007). ${ }^{b}$ Retention index value determined relative to $n$-alkanes (C9-C24) on the DB-5 GC column. * Percentage of compounds class in analyzed essential oil samples. 


\subsection{Fumigant and Persistence Toxicity of A. maritima Oil against Pulse Beetle}

Fumigant toxicity and persistence of $A$. maritima oil against pulse beetle were presented in Tables $2-4$. The oil showed more promising toxicity against $C$. maculatus $\left(\mathrm{LC}_{50}=1.91\right.$ and $\left.0.56 \mathrm{mg} / \mathrm{L}\right)$ after 24 , and $48 \mathrm{~h}$ of treatment respectively as compared to C. chinensis $\left(\mathrm{LC}_{50}=2.06\right.$ and $\left.1.17 \mathrm{mg} / \mathrm{L}\right)$ (Table 2). Based on persistence study, A. maritima oil showed significantly more promising in protecting the grains/seeds (Table 3 ) against C. chinensis $\left(82 \%\right.$ mortality) up to 10 days of storage $\left(\mathrm{F}_{3,19}=55.30 ; p<0.0001\right)$ as compared to $C$. maculatus ( $44 \%$ mortality) $\left(\mathrm{F}_{3,19}=33.47 ; p<0.0001\right)$. A. maritima oil showed moderate residual toxicity of 10-20 days only, later toxicity was gradually decreased and became 8 and $0 \%$ mortality, against $C$. chinensis and C. maculatus, respectively after 40 days of storage. A. maritima oil also showed residual toxicity with the lethal time taken to kill $50 \%$ of test insects was 4.49 days and 9.33 days for $C$. chinensis and C. maculatus, respectively (Table 4). The seeds used for the persistence study also showed $100 \%$ germination within $24 \mathrm{~h}$.

Table 2. Fumigant toxicity of $A$. maritima oil against $C$. chinensis and C. maculatus.

\begin{tabular}{cccccc}
\hline \multicolumn{7}{c}{ C. chinensis } \\
\hline Time & LC $_{\mathbf{5 0}} \mathbf{( m g / L )}$ & Confidence Limits $(\mathbf{m g} / \mathrm{L})$ & Slope $\pm \mathbf{S E}$ & Chi-Square & $p$-Value \\
\hline $12 \mathrm{~h}$ & 2.90 & $2.45-3.62$ & $3.06 \pm 0.57$ & 2.83 & 0.42 \\
$24 \mathrm{~h}$ & 2.06 & $1.72-2.45$ & $3.08 \pm 0.51$ & 5.15 & 0.16 \\
$48 \mathrm{~h}$ & 1.17 & $0.86-1.43$ & $2.96 \pm 0.51$ & 2.95 & 0.40 \\
\hline \multicolumn{7}{c}{ C. maculatus } \\
\hline $12 \mathrm{~h}$ & 3.93 & $2.83-6.29$ & $1.58 \pm 0.29$ & 2.51 & 0.47 \\
$24 \mathrm{~h}$ & 1.91 & $0.96-3.63$ & $0.87 \pm 0.25$ & 0.47 & 0.93 \\
$48 \mathrm{~h}$ & 0.56 & $0.23-0.88$ & $1.37 \pm 0.31$ & 4.42 & 0.22 \\
\hline
\end{tabular}

Table 3. Residual toxicity of C. chinensis and C. maculatus adults fed A. maritima oil-treated grains stored for different periods.

\begin{tabular}{|c|c|c|c|c|}
\hline \multirow{3}{*}{ Days after Treatment } & \multicolumn{4}{|c|}{ Percent Mortality ( 24 and $48 \mathrm{~h}$ after Treatment) } \\
\hline & \multicolumn{2}{|c|}{ C. chinensis } & \multicolumn{2}{|c|}{ C. maculatus } \\
\hline & $24 \mathrm{~h}$ & $48 \mathrm{~h}$ & $24 \mathrm{~h}$ & $48 \mathrm{~h}$ \\
\hline $10 \mathrm{DAT}$ & $50 \pm 3.16 \mathrm{a}$ & $82 \pm 2.00 \mathrm{a}$ & $28 \pm 3.74 \mathrm{a}$ & $44 \pm 4.00 \mathrm{a}$ \\
\hline 20 DAT & $6 \pm 4.00 \mathrm{a}$ & $18 \pm 3.74 b$ & $20 \pm 3.16 \mathrm{a}$ & $26 \pm 4.00 \mathrm{~b}$ \\
\hline $30 \mathrm{DAT}$ & $4 \pm 2.44 \mathrm{a}$ & $8 \pm 2.00 \mathrm{c}$ & $4 \pm 2.44 b$ & $8 \pm 3.74 \mathrm{c}$ \\
\hline 40 DAT & $0 \pm 0.00 \mathrm{a}$ & $8 \pm 2.00 c$ & $4 \pm 2.44 b$ & $0 \pm 0.00 \mathrm{c}$ \\
\hline F value & $\begin{array}{c}\mathrm{F}_{3,19}=54.07 \\
p<0.0001\end{array}$ & $\begin{array}{c}\mathrm{F}_{3,19}=55.30 \\
p<0.0001\end{array}$ & $\begin{array}{c}\mathrm{F}_{3,19}=16.00 \\
p<0.0001\end{array}$ & $\begin{array}{c}\mathrm{F}_{3,19}=33.47 \\
p<0.0001\end{array}$ \\
\hline
\end{tabular}

* Means followed by the same letters within a column do not differ significantly by Tukey's HSD ( $p \leq 0.05)$.

Table 4. $\mathrm{LT}_{50}$ values of A. maritima oil-treated grains (higher concentration) against adults of C. chinensis and C. maculatus at different storage periods of 10,20,30, and 40 days.

\begin{tabular}{cccccc}
\hline Time & $\mathbf{L T}_{\mathbf{5 0}}$ (Days) & $\begin{array}{c}\text { Confidence } \\
\text { Limits (Days) }\end{array}$ & Slope $\pm \mathbf{S E}$ & Chi-Square & $p$-Value \\
\hline C. chinensis & 14.49 & $12.79-16.11$ & $6.26 \pm 0.79$ & 2.59 & 0.27 \\
C. maculatus & 9.33 & $5.88-11.96$ & $2.48 \pm 0.62$ & 1.70 & 0.43 \\
\hline
\end{tabular}

\subsection{Repellency of A. maritima Oil against Pulse Beetle}

Repellency of $A$. maritima oil against $C$. chinensis after $1,2,3,4$, and $5 \mathrm{~h}$ of after treatment was presented in Table 5. Higher concentration $(8 \mathrm{mg} / \mathrm{L})$ of $A$. maritima oil showed significantly higher repellence $(92 \%)$ after $1 \mathrm{~h}\left(\mathrm{~F}_{4,24}=11.97 ; p<0.0001\right)$ and remain effective up to $5 \mathrm{~h}$ ( $88 \%$ repellence) and was at par with $6 \mathrm{mg} / \mathrm{L}$ ( $80 \%$ repellence) as compared to 
lower concentrations (12-36\% repellence). Similarly, A. maritima oil at $8 \mathrm{mg} / \mathrm{L}$ showed significantly higher repellence $(96 \%)$ against $C$. maculatus after $1 \mathrm{~h}\left(\mathrm{~F}_{4,24}=10.61 ; p<0.0001\right)$ and was at par with $6 \mathrm{mg} / \mathrm{L}$ (76\% repellence) as compared to lower concentrations (28-56\% repellence). Based on the repellent index (Table S1), all the concentrations of the A. maritima oil showed indifferent (I).

Table 5. Repellent activity of $A$. maritima oil against $C$. chinensis and C. maculatus.

\begin{tabular}{|c|c|c|c|c|c|}
\hline \multirow{2}{*}{ Conc. (mg/L) } & \multicolumn{5}{|c|}{$\%$ Repellence (Hours after Treatment) } \\
\hline & $1 \mathrm{~h}$ & $2 \mathrm{~h}$ & $3 \mathrm{~h}$ & $4 \mathrm{~h}$ & $5 \mathrm{~h}$ \\
\hline & \multicolumn{5}{|c|}{ C. chinensis } \\
\hline 1 & $24.00 \pm 7.48 c$ & $24.00 \pm 4.00 \mathrm{~d}$ & $16.00 \pm 4.00 \mathrm{c}$ & $12.00 \pm 4.90 c$ & $12.00 \pm 4.90 \mathrm{c}$ \\
\hline 2 & $44.00 \pm 7.48 c$ & $44.00 \pm 7.48 \mathrm{~cd}$ & $40.00 \pm 8.94 \mathrm{bc}$ & $28.00 \pm 4.90 \mathrm{bc}$ & $30.00 \pm 6.32 \mathrm{bc}$ \\
\hline 4 & $56.00 \pm 11.66 \mathrm{bc}$ & $56.00 \pm 11.66 \mathrm{bc}$ & $52.00 \pm 10.20 \mathrm{~b}$ & $36.00 \pm 16.00 \mathrm{bc}$ & $36.00 \pm 7.48 \mathrm{bc}$ \\
\hline 6 & $80.00 \pm 6.32 \mathrm{ab}$ & $76.00 \pm 4.00 \mathrm{ab}$ & $72.00 \pm 8.00 \mathrm{ab}$ & $60.00 \pm 14.14 \mathrm{ab}$ & $60.00 \pm 14.14 \mathrm{ab}$ \\
\hline \multirow[t]{3}{*}{8} & $92.00 \pm 4.90 \mathrm{a}$ & $88.00 \pm 4.90 \mathrm{a}$ & $88.00 \pm 4.90 \mathrm{a}$ & $88.00 \pm 4.90 \mathrm{a}$ & $88.00 \pm 4.90 \mathrm{a}$ \\
\hline & $\begin{array}{c}\mathrm{F}_{4,24}=11.97 \\
p<0.0001\end{array}$ & $\begin{array}{c}\mathrm{F}_{4,24}=13.00 \\
p<0.0001\end{array}$ & $\begin{array}{c}\mathrm{F}_{4,24}=13.56 \\
p<0.0001\end{array}$ & $\begin{array}{c}\mathrm{F}_{4,24}=8.36 \\
p<0.0001\end{array}$ & $\begin{array}{c}\mathrm{F}_{4,24}=12.60 \\
p<0.0001\end{array}$ \\
\hline & \multicolumn{5}{|c|}{ C. maculatus } \\
\hline 1 & $28.00 \pm 8.00 \mathrm{c}$ & $20.00 \pm 6.32 \mathrm{~d}$ & $16.00 \pm 4.00 \mathrm{~d}$ & $16.00 \pm 7.48 c$ & $16.00 \pm 4.00 \mathrm{c}$ \\
\hline 2 & $40.00 \pm 10.95 c$ & $32.00 \pm 4.90 \mathrm{~cd}$ & $28.00 \pm 8.00 \mathrm{~cd}$ & $28.00 \pm 4.90 \mathrm{bc}$ & $24.00 \pm 4.00 \mathrm{bc}$ \\
\hline 4 & $56.00 \pm 9.80 \mathrm{bc}$ & $48.00 \pm 4.90 \mathrm{bc}$ & $44.00 \pm 4.00 \mathrm{bc}$ & $40.00 \pm 6.32 \mathrm{bc}$ & $36.00 \pm 7.48 \mathrm{bc}$ \\
\hline 6 & $76.00 \pm 7.48 \mathrm{ab}$ & $68.00 \pm 4.90 \mathrm{~b}$ & $56.00 \pm 7.48 \mathrm{~b}$ & $52.00 \pm 10.20 \mathrm{~b}$ & $48.00 \pm 10.20 \mathrm{~b}$ \\
\hline \multirow[t]{2}{*}{8} & $96.00 \pm 4.00 \mathrm{a}$ & $92.00 \pm 4.90 \mathrm{a}$ & $88.00 \pm 4.90 \mathrm{a}$ & $88.00 \pm 8.00 \mathrm{a}$ & $84.00 \pm 7.48 \mathrm{a}$ \\
\hline & $\begin{array}{c}\mathrm{F}_{4,24}=10.61 \\
p<0.0001\end{array}$ & $\begin{array}{c}\mathrm{F}_{4,24}=30.29 \\
p<0.0001\end{array}$ & $\begin{array}{c}\mathrm{F}_{4,24}=21.95 \\
p<0.0001\end{array}$ & $\begin{array}{c}\mathrm{F}_{4,24}=13.25 \\
p<0.0001\end{array}$ & $\begin{array}{c}\mathrm{F}_{4,24}=14.29 \\
p<0.0001\end{array}$ \\
\hline
\end{tabular}

${ }^{*}$ Mean of five replications; Means followed by the same letters within a column do not differ significantly by Tukey's HSD $(p \leq 0.05)$.

\subsection{Ovipositional Deterrence of A. maritima Oil against Pulse Beetle}

Results on ovipositional deterrence of $A$. maritima oil against $C$. chinensis and C. maculatus was presented in Table 6 and Tables S2 and S3. A. maritima oil was showed promising deterrence against $C$. chinensis $\left(\mathrm{OD}_{50}=2.3,3.09\right.$ and $\left.3.30 \mathrm{mg} / \mathrm{L}\right)$ after 24,48 , and $72 \mathrm{~h}$ of treatment, respectively (Table 6) as compared to $C$. maculatus $\left(\mathrm{OD}_{50}=2.89,3.36\right.$ and $4.01 \mathrm{mg} / \mathrm{L}$ ). With respect to percent deterrence against $C$. chinensis, the A. maritima oil at higher concentration $(12 \mathrm{mg} / \mathrm{L})$ reported $100 \%$ deterrence against $C$. chinensis at $24 \mathrm{~h}$ of treatment $\left(\mathrm{F}_{4,24}=16.08 ; p<0.0001\right)$ and was at par with other concentrations $(78.2$ to $94.38 \%$ deterrence) except 2 and $1 \mathrm{mg} / \mathrm{L}$. Similarly, 48 and $72 \mathrm{~h}$ after treatment, $A$. maritima oil at $12 \mathrm{mg} / \mathrm{L}$ showed higher deterrence (98.28-100\%) and was at par with $8 \mathrm{mg} / \mathrm{L}$ (92.34 to 93.28\% deterrence) and was followed by 4 and $2 \mathrm{mg} / \mathrm{L}$ which were at par as compared to lower concentration. Similarly, for C. maculatus, A. maritima oil at $8 \mathrm{mg} / \mathrm{L}$ showed $100 \%$ deterrence after $24 \mathrm{~h}$ against $C$. maculatus $\left(\mathrm{F}_{4,24}=30.38 ; p<0.0001\right)$ and was at par with $4 \mathrm{mg} / \mathrm{L}(86.54 \%)$ followed by $2 \mathrm{mg} / \mathrm{L}(70 \%)$ as compared to lower concentrations. At $48 \mathrm{~h}$ after treatment same trend was observed as that of $24 \mathrm{~h}$. At $72 \mathrm{~h}$, A. maritima oil at $8 \mathrm{mg} / \mathrm{L}$ showed significantly higher deterrence $(81.78 \%)\left(\mathrm{F}_{4,24}=41.78 ; p<0.0001\right)$ and was at par with all other concentrations except lower concentration. 
Table 6. Ovipositional deterrence of $A$. maritima oil against $C$. chinensis and C. maculatus adults.

\begin{tabular}{cccccc}
\hline \multicolumn{7}{c}{ C. chinensis } \\
\hline Time (h) & OD $_{\mathbf{5 0}}(\mathbf{m g} / \mathrm{L})$ & $\begin{array}{c}\text { Confidence Limits } \\
(\mathbf{m g} / \mathbf{L})\end{array}$ & Slope \pm SE & Chi-Square & $p$-Value \\
\hline $24 \mathrm{~h}$ & 2.30 & $1.74-2.80$ & $2.36 \pm 0.27$ & 3.59 & 0.31 \\
\hline $48 \mathrm{~h}$ & 3.09 & $2.50-3.66$ & $2.28 \pm 0.23$ & 3.68 & 0.30 \\
\hline $72 \mathrm{~h}$ & 3.30 & $2.65-3.93$ & $2.11 \pm 0.21$ & 1.83 & 0.61 \\
\hline & & & C. maculatus & & \\
\hline $24 \mathrm{~h}$ & 2.89 & $2.51-3.30$ & $2.34 \pm 0.19$ & 4.42 & 0.22 \\
\hline $48 \mathrm{~h}$ & 3.36 & $2.85-3.90$ & $1.94 \pm 0.17$ & 3.06 & 0.38 \\
\hline $72 \mathrm{~h}$ & 4.01 & $3.32-4.79$ & $1.55 \pm 0.15$ & 4.80 & 0.19 \\
\hline
\end{tabular}

\subsection{Detoxification Enzyme Inhibition of A. maritima Oil against Pulse Beetle}

Detoxifying enzyme (AChE and GST) activities of A. maritima oil against $C$. chinensis and C. maculatus after $12 \mathrm{~h}$ of treatment is presented (Table S4 and Figure 1). Significant differences were not observed $(p>0.001)$ among the concentrations of oil (4 to $10 \mathrm{mg} / \mathrm{L}$ ) in inhibiting the enzyme GST and AChE in C. chinensis. Similarly, higher concentrations of A. maritima oil at 6 and $8 \mathrm{mg} / \mathrm{L}$ significantly inhibited the GST (7.14 and $5.61 \mathrm{n} \mathrm{mol} / \mathrm{min} / \mathrm{mL})\left(\mathrm{F}_{4,14}=14.6 ; p<0.003\right)$ and $\mathrm{AChE}(\mathrm{mU} / \mathrm{mg})\left(\mathrm{F}_{4,14}=8.14 ; p<0.003\right)$ in C. maculatus and were at par as compared to lower concentrations and control.

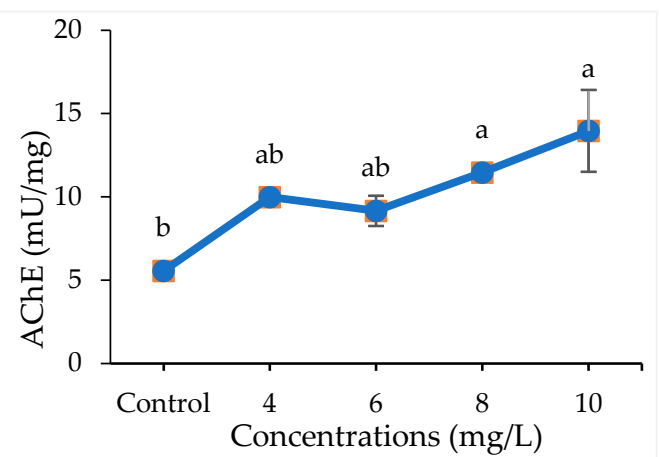

(a)

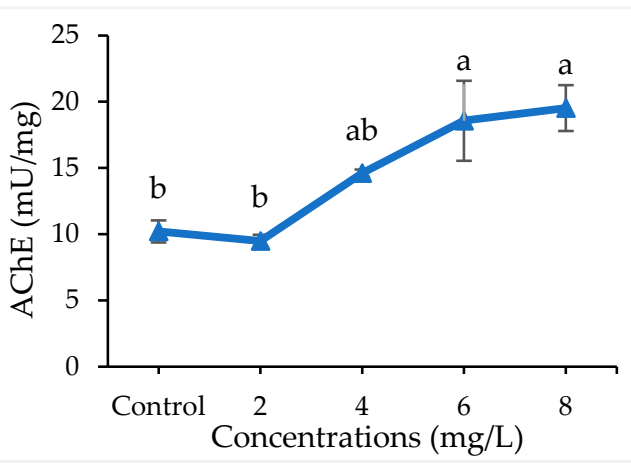

(c)

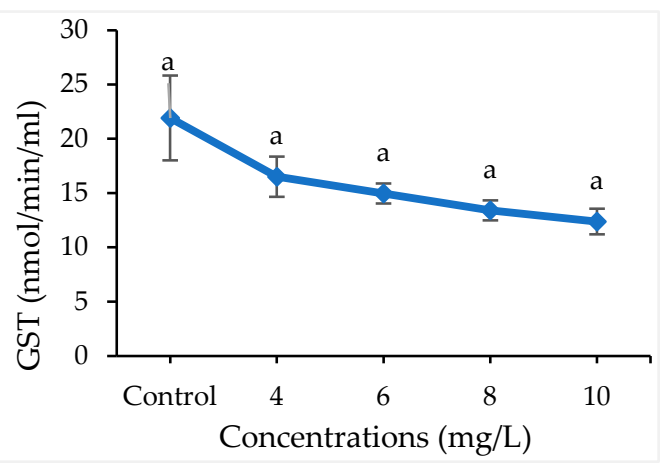

(b)

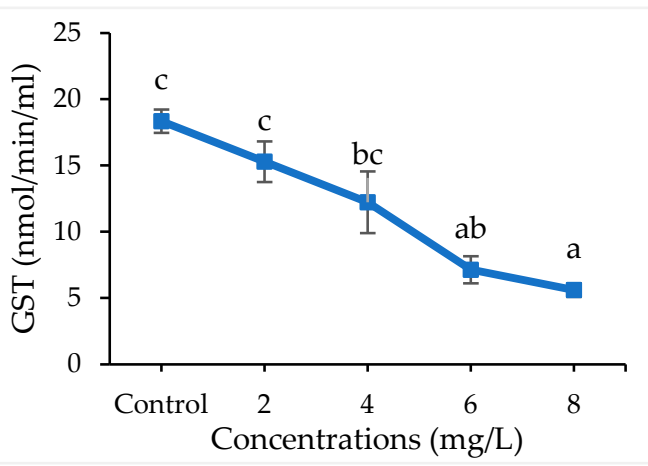

(d)

Figure 1. Detoxification enzyme inhibition activities: AChE (a) and GST (b) in C. chinensis; AChE (c) and GST (d) in C. maculatus treated with A. maritima oil; Bars represents a standard error ( \pm SE) of three replications; Means followed by the same letters within a figure do not differ significantly by Tukey's HSD $(p \leq 0.05)$. 


\section{Discussion}

The chemical composition, insecticidal, and enzyme inhibition activities of $A$. maritima oil against $C$. chinensis and $C$. maculatus are discussed. Present results revealed that A. maritima oil is rich in oxygenated monoterpenes $(45.73 \%)$ and monoterpene hydrocarbons $(28.11 \%)$. The major constituents of the oil were 1,8-cineole, bornyl acetate, myrcene, and sabinene which account for more than $75.25 \%$ of the total oil. The earlier studies on Artemisia species also reported 1,8-cineole was the major compound $(9.91,12.96$, and $19.59 \%$ ) in the EO of A. sieberi, A. gmelinii, and A. herba alba, respectively [27-29] but lesser than the present study $(41.14 \%)$. Similarly, 1,8-cineole present in A. maritima oil (23.6-25\%) was also lesser [30-32] than in the present study. The $\beta$-myrcene (5.09-5.83\%) in $A$. campestris and A. absinthium was also lesser $[27,33]$ than present study $(9.59 \%)$. The variation in the chemical constituents might be due to environmental conditions (climate, season, and geographical variation), location/altitude, stage of the plant, time of collection, species/chemotype, and nutritional status of the plant [34-36].

EO of different species of Artemisia showed biological activity to pests. As per the information, the current report is the earliest to disclose that the essential oil of A. maritima showed promising results in toxicity, repellent, and ovipositional deterrence against C. chinensis and $C$. maculatus adults. The previous studies also reported that the EO from other Artemisia species including A. annua [19], A. judaica [20], A. monosperma [37], A. dracunculus, A. santonicum, A. spicigera [21], A. herba-alba, A. campestris, and A. absinthium [27], A. ordosica [38], A. vulgaris [22], A. scoparia [23], A. sieberi [24] and A. annua [39] showed contact, fumigant, repellent, and ovipositional activities against pulse beetle. Insecticidal activities of the EO depend upon the major constituents, concentration, application method, stage, and type of insect. $[28,40,41]$ In the present study, our results revealed that $A$. maritima oil showed fumigant toxicity against $C$. chinensis $\left(\mathrm{LC}_{50}=1.17-2.06 \mathrm{mg} / \mathrm{L}\right)$ and $C$. maculatus (0.56-1.91 mg/L) within 24-48 h as compared to A. herba alba, A. albsinthium and A. campestris $\left(\mathrm{LC}_{50}=8.3-30.5 \mu \mathrm{L} / \mathrm{L}\right.$ air) against Bruchus rufimanus [27]. In a related study, A. dracunculus, A. santonicum, and A. spicigera (5 $\mu \mathrm{L} / \mathrm{L}$ air) showed $88-95 \%$ mortality [21] and $A$. sieberi showed promising fumigant toxicity $\left(\mathrm{LC}_{50}=1.45 \mu \mathrm{L} / \mathrm{L}\right.$ air) against $C$. maculutus [24]. Similarly, the EOs of Mentha spicata, M. piperita, and Tagetes minuta showed promising fumigant toxicity against adults of $C$. chinensis $\left(\mathrm{LC}_{50}=0.9-1.4 \mu \mathrm{L} / \mathrm{mL}\right)$ and C. maculatus $\left(\mathrm{LC}_{50}=1.1\right.$ to $\left.2.0 \mu \mathrm{L} / \mathrm{mL}\right)$ [4].

In the present study, the EO of A. maritima showed $84-96 \%$ repellence and ovipositional deterrence $\left(\mathrm{OD}_{50}=3.30-4.01 \mathrm{mg} / \mathrm{L}\right)$ against $C$. chinensis and $C$. maculatus. The present results are similar to the earlier studies, where EOs of M. spicata, M. piperita, and T. minuta showed 84 to $96 \%$ repellency [4]. In another study, the EO of Ocimum gratissimum exhibited 73-93\% repellence against C. chinensis after $24 \mathrm{~h} \mathrm{[42].} \mathrm{Similarly,} \mathrm{M.} \mathrm{spicata} \mathrm{and}$ M. piperita oil at $12 \mu \mathrm{L} / \mathrm{mL}$ also showed $100 \%$ ovipositional inhibition against C. chinensis and C. maculatus [4]. The EOs of Lippia alba Mill. and Callistemon lanceolatus (Curtis) at $100 \mu \mathrm{L} / \mathrm{L}$ [43] reported 66-96\% oviposition deterrent against pulse beetle; whereas the EOs of Illicium verum and Croton anisatum at $17.5 \mu \mathrm{L} / \mathrm{L}$ [44] also showed 100\% oviposition deterrent against $C$. chinensis as compared to the present study.

The insecticidal activities of $A$. maritima oil against targeted insects in the present study may be due to the presence of major compounds including 1,8-cineole, bornyl acetate, myrcene, and sabinene. Current results also confirmed with the earlier studies in which insecticidal activities of oils are due to monoterpenoids and sesquiterpenoids which are volatile and rather lipophilic compounds that can penetrate insect cuticle and interfere with their physiological functions [45-47]. Du to th volatile nature of EOs, they act as a fumigant and kill the stored-grain insects by asphyxiation. The insecticidal activities also depend on nature and type of components, application dose/concentrations [48-50].

Normally, insects utilize detoxification enzymes to metabolize xenobiotics [51-53]. However, enzymes can be induced by botanical and chemical insecticides which play a significant role in developing resistance to pests [54,55]. GST enzyme involved in detoxification of insecticides of organophosphate, organochlorines, pyrethroids, carbamates, etc., [56,57]. 
The chemical constituents present in the EOs and their blends, inhibit the GST activity [58-60]. In the current studies, A. maritima oil was not significantly inhibiting GST/AChE enzyme in C. chinensis and AChE in C. maculatus. However, higher concentrations of A. maritima oil showed inhibition of GST enzyme in C. maculatus and these results confirm the findings of previous work in which A. brachyloba oil significantly inhibited the GST in T. castaneum after $24 \mathrm{~h}$ but the same oil also inhibit the AChE after $60 \mathrm{~h}$ of treatment [61]. In a similar study, eucalyptol and caryophyllene oxide isolated from $\mathrm{EO}$ of A. lavandulaefolia showed inhibition of GST and CarE in the larvae of Plutella xylostella after $24 \mathrm{~h}$ [26]. Based on insecticidal activities, A. maritima oil showed promising fumigant toxicity, repellence, ovipositional deterrence, and enzyme inhibition (GST and AChE) activities against $C$. chinensis and C. maculatus.

\section{Materials and Methods}

\subsection{Plant Material}

The plant material was collected from Keylong (Lahaul \& Spiti District, H.P, India) (latitude $32.571^{\circ} \mathrm{N}$ and longitude $77.041^{\circ} \mathrm{E}$ ) of Himachal Pradesh during September 2019. The specimens are authenticated by the Taxonomist, and a voucher specimen (PLP 17794) was deposited in the herbarium.

\subsection{Extraction of A. maritima Oil}

The whole plant (aerial parts) material of A. maritima was dried under shade for 10 days and chopped into small pieces. About $10 \mathrm{~kg}$ plant material was used for extraction of oil by hydro-distillation in Clevenger apparatus as per the method followed [16]. The yield obtained was $3.4 \mathrm{~mL}$ and was kept below $4{ }^{\circ} \mathrm{C}$ until further use.

\subsection{Gas Chromatography Analysis}

The composition of EO determined by gas chromatography (GC) on a Shimadzu GC 2010 equipped with DB-5 (J \& W Scientific, Folsom, CA, USA) fused silica capillary column (30 $\mathrm{m} \times 0.25 \mathrm{~mm}$ i.d., $0.25 \mu \mathrm{m}$ film thickness) with a flame ionization detector (FID) [16,62]. The GC oven temperature programmed at $70{ }^{\circ} \mathrm{C}$ (initial temperature) held for 4 min and then increased at a rate of $4{ }^{\circ} \mathrm{C} / \mathrm{min}$ to $220^{\circ} \mathrm{C}$ and held for $5 \mathrm{~min}$. The injector temperature was $240{ }^{\circ} \mathrm{C}$, the detector temperature, $260^{\circ} \mathrm{C}$, and the samples were injected in split mode. The carrier gas was nitrogen at a column flow rate of $1.05 \mathrm{~mL} / \mathrm{min}(100 \mathrm{kPa})$. The sample's retention indices (RI) were determined based on homologous $n$-alkane hydrocarbons under the same conditions.

\subsection{Test Insect}

C. chinensis and C. maculatus were maintained on green gram seeds in plastic jars under controlled conditions $\left(27-28{ }^{\circ} \mathrm{C}\right.$ and $60 \pm 5 \%$ humidity) in the Entomology laboratory, Agrotechnology Division, CSIR-IHBT, Palampur for $>50$ generations. The newly emerged adults (2-3 days old) were used for the study.

\subsection{Fumigant Toxicity of A. maritima Oil against Pulse Beetle}

Five different concentrations of A. maritima oil for $C$. chinensis $(10,8,6,4$, and $2 \mathrm{mg} / \mathrm{L})$ and $C$. maculatus $(8,4,2,1$, and $0.5 \mathrm{mg} / \mathrm{L})$ were prepared based on preliminary evaluation for dose-response bioassay against pulse beetle adults. The fumigant toxicity assay was studied on glass desiccators (2.5 L capacity). Five grams of green gram were taken in a glass Petri dish and kept at the bottom of the desiccators in which 10 adults are released. In another Petri dish, Whatman No. 9 filter paper was placed and kept at the top of the desiccators. Five concentrations of A. maritima oil were applied on the filter paper separately by using a micropipette and then the lid of the desiccators was closed to make it airtight. The desiccators were kept in the controlled laboratory conditions for recording the mortality at $24 \mathrm{~h}$ intervals. There are five treatments/concentrations, and each treatment was replicated thrice. 


\subsection{Persistence of A. maritima Oil against Pulse Beetle}

The persistence of $A$. maritima oil was carried out as per the standard method followed by Nenaah [8]. Higher concentrations ( 4 and $8 \mathrm{mg} / \mathrm{L}$ ) of oil were used against C. chinensis and C. maculatus, respectively. Briefly, sterilized green gram seeds were treated with two concentrations of EO and seeds were vigorously hand-shaken for 20-30 s for thorough coating. After evaporation of the solvent, the treated grains were packed in jute sacks $(20-30 \mathrm{~cm})$ and stored in dark conditions. Samples of treated seeds $(20 \mathrm{~g})$ were withdrawn after 10, 20,30, and 40 days of treatment and then 10 adults (1 day old) are released in the Petri-dish ( $9 \mathrm{~cm}$ diameter). The same no. was also used for the control treated with $0.05 \%$ of Triton-X 100 LR water. Each treatment was replicated five times. The insects were exposed to treated seeds were continued for $48 \mathrm{~h}$ and then mortality was recorded. For germination study, the treated green gram seeds with $A$. maritima oil were placed on moistened cotton in a Petri dish and incubated under laboratory conditions. Observations on the number of seeds germinated were recorded after 24 and $48 \mathrm{~h}$.

\subsection{Repellent Activity of A. maritima Oil against Pulse Beetle}

Repellent activity of $A$. maritima oil was tested against $C$. chinensis and $C$. maculatus as per the method followed by Eccles et al. [63]. Briefly, five concentrations (8, 6, 4, 2, $1 \mathrm{mg} / \mathrm{L}$ ) were prepared from stock solutions. The Whatman No. 9 filter paper (diameter $9 \mathrm{~cm}$ ) was cut and marked with a pencil into two halves and each labeled as treated (T) and untreated (UT). Filter papers were transferred to Petri plates (diameter $9 \mathrm{~cm}$ ) and treated with required concentrations of EOs and then allowed to air dry for $15 \mathrm{~min}$. Ten adults (3-4 days old) were released in the center of the filter paper containing ten grains, and the plates were sealed with parafilm to prevent the escape of adults. The dispersal of the beetles on each side of the filter paper was recorded after treatment. Observation on repellency was recorded at 1, 2, 3, 4, and $5 \mathrm{~h}$ after treatment. In this study, there were five treatments, and each treatment was replicated five times. About 250 insects were used in different treatments ( 5 treatments $\times 50$ insects $=250$ insects). The Percent repellency (PR) [64] was calculated based on the formula: $\mathrm{PR}=[(\mathrm{Nc}-\mathrm{Nt}) /(\mathrm{Nc}+\mathrm{Nt})] \times 100$. Where $\mathrm{Nc}=$ number of insects on control half of filter paper after required exposure interval; $\mathrm{Nt}=$ number of insects on treated half of filter paper after required exposure interval.

The Repellent Index (RI) [65] was calculated based on the formula; RI = 2G/G+P. Where $G=$ number of adults on the treated side and $P=$ number of adults on the untreated side. The repellent index of EOs is considered as repellent, attractant, or indifferent based on the mean value of RI and its respective standard deviation (SD). If the mean RI is higher than $1+\mathrm{SD}$, the oil is an attractant, while if the mean RI is less than 1-SD, the oil is repellent, and for the mean RI in between $1-$ SD and $1+$ SD, the oil is indifferent.

\subsection{Ovipositional Deterrent Activity of A. maritima Oil against $C$. chinensis and C. maculatus}

The ovipositional deterrent of $A$. maritima oil against $C$. chinensis and $C$. maculatus was studied as per the method followed by Eccles et al. [63]. Briefly, five concentrations $(12,8,4$, $2,1 \mathrm{mg} / \mathrm{L})$ for $C$. chinensis and C. maculatus $(8,6,4,2,1 \mathrm{mg} / \mathrm{L})$ were prepared from stock solutions by mixing EOs in acetone. Seeds ( 30 no./plate) dipped in different concentrations for 10s, then removed and placed on filter paper to air dry for $15 \mathrm{~min}$. Treated seeds were placed in a Petri plate (diameter $9 \mathrm{~cm}$ ) and then ten adults ( 5 male and 5 female) of one day old were released. Petri plates were sealed with parafilm to prevent the escape of the adults. For the control, seeds were treated with acetone only. There were five treatments, and each treatment was replicated five times. The number of eggs laid on seeds of green gram was observed from 24 to $72 \mathrm{~h}$. The percentage of oviposition inhibition was calculated by using the formula [45].

$\mathrm{OI}=[(\mathrm{NC}-\mathrm{NT}) / \mathrm{NC}] \times 100$. where $\mathrm{NT}=\mathrm{No}$. of eggs in untreated and $\mathrm{NT}=\mathrm{No}$. of eggs laid in treated. 


\subsection{Detoxification Enzyme Inhibition of A. maritima Oil against Pulse Beetle}

\subsubsection{Sample Preparation}

Detoxification enzyme (Glutathione-S-Transferase and Acetylcholinesterae) inhibition activities were performed as per the standard methods $[60,66,67]$. Four different concentrations of A. maritima oil $(4,6,8$, and $10 \mathrm{mg} / \mathrm{L}$ for $C$. chinensis and 2, 4, 6, and $8 \mathrm{mg} / \mathrm{L}$ for C. maculatus) were chosen for detoxification enzyme inhibition activity based on fumigant toxicity assay described in Section 4.5. The adults who survived after $12 \mathrm{~h}$ of treatment (7-8 adults weighing $20 \mathrm{mg} /$ concentration) were collected for enzyme assay. The adults in each test concentration were transferred to a centrifuge tube and homogenized in $0.1 \mathrm{M}$ phosphate buffer ( $\mathrm{pH} 7.4)$ in a ratio of 1:9. The weight of an adult (mg): the volume of buffer $(\mathrm{mL})$ was kept in a ratio of 1:9. The adults were then homogenized with a homogenizer (Tarsons Micro Pestle). The homogenate was transferred immediately under ice bath conditions and then centrifuged at $12,000 \mathrm{rpm}$ and $4{ }^{\circ} \mathrm{C}$ for $30 \mathrm{~min}$. The supernatant was taken into a new centrifuge tube for protein estimation by Bradford assay [68] for all the concentrations before proceeding for enzyme assays. The same assay was repeated thrice for separate homogenates and then average values were taken for protein estimation.

\subsubsection{Protein Estimation}

Protein estimation was done using the Bradford method [68] by adding $2 \mu \mathrm{L}$ of homogenate, $38 \mu \mathrm{L}$ of MilliQ to $160 \mu \mathrm{L}$ of Bradford reagent in triplicates. After incubation of the mixture for $15 \mathrm{~min}$ at room temperature, the absorbance was measured at $595 \mathrm{~nm}$. Absorbance was converted into protein concentrations and dilutions were made with respect to lower concentrations for the AChE assay.

\subsubsection{AChE Assay}

The diluted $25 \mu \mathrm{L}$ homogenates in triplicates were incubated for $30 \mathrm{~min}$ at room temperature with $25 \mu \mathrm{L}$ of the reaction mixture ( $50 \mu \mathrm{L}$ of DTNB, $50 \mu \mathrm{L}$ of Acetothiocholine, $900 \mu \mathrm{L}$ of assay buffer). The AChE activity was spectrophotometrically measured at $410 \mathrm{~nm}$ in a microplate reader (Biotek SYNERGY H1 Microplate Spectrophotometer). The enzyme activities were expressed as micromolar per milligram protein per minute $(\mu \mathrm{mol} / \mathrm{min} / \mathrm{mg})$. For the determination of $\mathrm{AChE}$, the Acetylcholinesterase Assay Kit was procured from Abcam, UK.

\subsubsection{GST Assay}

The reaction contains $1000 \mu \mathrm{L}$ of the solution, in which $75 \mu \mathrm{L}$ of Assay buffer, $10 \mu \mathrm{L}$ of the homogenized sample, $10 \mu \mathrm{L}$ of glutathione were added. To initiate the reactions, $5 \mu \mathrm{L}$ CDNB was added to each well in triplicates to microplate at room temperature. To measure the enzyme kinetics, a 96 well microplate was loaded with reaction solution and shaken for $10 \mathrm{~s}$. After $60 \mathrm{~s}$ of lag time, the absorbance was read at $340 \mathrm{~nm}$ and the homogenates were read for $20 \mathrm{~min}$ at $37^{\circ} \mathrm{C}$ with a microplate reader. The GST activity was determined from the extinction coefficient of $0.0096 \mu \mathrm{M}^{-1} \mathrm{~cm}^{-1}$ for CDNB. The enzyme activities were expressed as micromolar per milligram protein per minute ( $\mu \mathrm{mol} / \mathrm{min} / \mathrm{mg}$ protein). For the determination of GST and AChE enzyme, the Glutathione-S-Transferase Assay Kit was procured from Cayman Chemical, 1180 E, Ellsworth Road, Ann Arbor, MI, USA.

\subsection{Statistical Analysis}

The data on fumigant toxicity, ovipositional deterrent, and persistence of A. maritima oil was compiled. Lethal concentration $\left(\mathrm{LC}_{50}\right)$, lethal time $\left(\mathrm{LT}_{50}\right)$, and ovipositional deterrence $\left(\mathrm{OD}_{50}\right)$ values were calculated by Probit analysis [69] using SPSS software v.16.0. The data on repellency, ovipositional deterrence, persistence, and enzyme inhibition were subjected to one-way ANOVA by SPSS software, and means were compared by Tukey's post hoc test to know the significant differences between treatments. The assumptions of normality and homogeneity of variance test for different parameters/variables and no data transformations were required. 


\section{Conclusions}

A. maritima oil showed promising fumigant toxicity $\left(\mathrm{LC}_{50}=0.56\right.$ to $\left.1.17 \mathrm{mg} / \mathrm{L}\right)$ against pulse beetle after $48 \mathrm{~h}$ of treatment. Higher concentrations of oil $(6$ and $8 \mathrm{mg} / \mathrm{L})$ significantly inhibited the GST enzyme in C. maculatus. However, the EO of A. maritima may be recommended for the control of pulse beetle particularly grains stored in bins based on a safe waiting period, persistence studies, and economics.

Supplementary Materials: The following are available online. Table S1: Repellent index of A. maritima oil against $C$. chinensis and $C$. maculatus. Table S2: Ovipositional inhibition of $A$. maritima oil against C. chinensis. Table S3: Ovipositional inhibition (deterrence) of A. maritima oil against C. maculatus. Table S4: Enzyme inhibition activity of $A$. maritima oil in C. chinensis and C. maculatus adults.

Author Contributions: N.C.: Data curation; Investigation; Validation; U.K.: Data curation; Investigation; Validation; S.K.D.: Data curation; Investigation; Validation; S.G.E.R.: Conceptualization; Formal analysis; Funding acquisition; Project Administration; Resources; Supervision; Roles/Writingoriginal draft; Writing - review \& editing. All authors have read and agreed to the published version of the manuscript.

Funding: This research was supported and funded by the Council of Scientific and Industrial Research, New Delhi, India for granting the proposal "CSIR Fast Track Translation Project"-MLP-0169 [No.33, FTT/FTC/ANB/2020-TMD-IND_INT].

Institutional Review Board Statement: Not applicable.

Informed Consent Statement: Not applicable.

Acknowledgments: Authors grateful to Council of Scientific and Industrial Research, New Delhi (INDIA) for funding "FTT project (MLP-0169)". The authors also thank Director CSIR-Institute of Himalayan Bioresource Technology, Palampur, Himachal Pradesh, India for encouragement and facilities.

Conflicts of Interest: The authors declare no conflict of interest.

Sample Availability: Not available.

\section{References}

1. Yadav, D.N.; Anand, T.; Sharma, M.; Gupta, R.K. Microwave technology for disinfestation of cereals and pulses: An overview. J. Food Sci. Technol. 2014, 51, 3568-3576. [CrossRef] [PubMed]

2. Rajendran, S. Postharvest pest losses. In Encyclopedia of Pest Management; Pimentel, D., Ed.; Marcel Dekker, Inc.: New York, NY, USA, 2002; pp. 654-656.

3. Mogbo, T.C.; Akunne, C.E.; Ononye, B.U. Evaluation of the efficacy of mixed leaf powders of Vernonia amygdalina (L.) and Azadirachta indica (A. Juss) against Callosobruchus maculatus (F.) (Coleoptera: Bruchidae). J. Biosci. Bioeng. 2013, 1, 86-95.

4. Jayaram, C.S.; Chauhan, N.; Dolma, S.K.; Reddy, S.G.E. Chemical composition and insecticidal activities of essential oils against the pulse beetle. Molecules 2022, 27, 568. [CrossRef] [PubMed]

5. Sharma, H.C.; Gowda, C.L.L.; Stevenson, P.C.; Ridsdill-Smith, T.J.; Clement, S.L.; Rao, G.V.R.; Romeis, J.; Miles, M.; El-Bouhssini, M. Host plant resistance and insect pest management in chickpea. Chickpea Breed. Manag. 2007, 520-537.

6. Varma, S.; Anadi, P. Biology of pulse beetle (Callosobruchus Chinensis Linn., Coleoptera: Bruchidae) and their management through botanicals on stored mung grains in Allahabad region. Legume Res. 2010, 33, 38-41.

7. Shaheen, F.A.; Khaliq, A. Management of pulse beetle, Callosobruchus chinensis L. (Coleoptera: Bruchidae) in stored chickpea using ashes, red soil powder and turpentine oil. Pak. Entomol. 2005, 27, 19-24.

8. Nenaah, G.E.; Ibrahim, S.I. Chemical composition and the insecticidal activity of certain plants applied as powders and essential oils against two stored-products coleopteran beetles. J. Pest Sci. 2011, 84, 393-402. [CrossRef]

9. Mbata, G.N.; Payton, M.E. Effect of monoterpenoids on oviposition and mortality of Callosobruchus maculatus (F.) (Coleoptera: Bruchidae) under hermetic conditions. J. Stored Prod. Res. 2013, 53, 4347. [CrossRef]

10. Nenaah, G.E. Chemical composition, toxicity and growth inhibitory activities of essential oils of three Achillea species and their nano-emulsions against Tribolium castaneum (Herbst). Ind. Crops Prod. 2014, 53, 252-260. [CrossRef]

11. Burt, S. Essential oils: Their antibacterial properties and potential applications in foods-a review. Int. J. Food Microbiol. 2004, 94, 223-253. [CrossRef]

12. Kumar, P.; Mishra, S.; Malik, A.; Satya, S. Insecticidal properties of Mentha species: A review. Ind. Crops Prod. 2011, 34, 802-817. [CrossRef] 
13. Chauhan, R.S.; Kitchlu, S.; Ram, G.; Kaul, M.K.; Tava, A. Chemical composition of capillene chemotype of Artemisia dracunculus L. from North-West Himalaya, India. Ind. Crops Prod. 2010, 31, 546-549. [CrossRef]

14. Abad, M.J.; Bedoya, L.M.; Apaza, L.; Bermejo, P. The Artemisia L. genus: A review of bioactive essential oils. Molecules 2012, 17, 2542-2566. [CrossRef] [PubMed]

15. Pandey, V.; Verma, R.S.; Chauhan, A.; Tiwari, R. Compositional characteristics of the volatile oils of three Artemisia spp. from western Himalaya. J. Essent. Oil Res. 2015, 27, 107-114. [CrossRef]

16. Walia, S.; Rana, A.; Singh, A.; Sharma, M.; Reddy, S.G.E.; Kumar, R. Influence of harvesting time on essential oil content, chemical composition and pesticidal activity of Artemisia maritima growing wild in the cold desert region of western Himalayas. J. Essent. Oil-Bear. Plants 2019, 22, 396-407. [CrossRef]

17. Tan, R.X.; Zheng, W.F.; Tang, H.Q. biologically active substances from the genus Artemisia. Planta Med. 1998, 64, 295-302. [CrossRef]

18. Li, G.; Yuan, M.; Li, H.; Deng, C.; Wang, Q.; Tang, Y.; Zhang, H.; Yu, W.; Xu, Q.; Zou, Y. Safety and efficacy of artemisininpiperaquine for treatment of COVID-19: An open-label, non-randomised and controlled trial. Int. J. Antimicrob. Agents 2021, 57, 106216. [CrossRef]

19. Tripathi, A.K.; Prajapati, V.; Aggarwal, K.K.; Khanuja, S.P.S.; Kumar, S. Repellency and toxicity of oil from Artemisia annua to certain stored-product beetles. J. Econ. Entomol. 2000, 93, 43-47. [CrossRef]

20. Abd-Elhady, H. Insecticidal activity and chemical composition of essential oil from Artemisia Judaica L. against Callosobruchus maculatus (F.) (Coleoptera: Bruchidae). J. Plant Prot. Res. 2012, 52, 347-352.

21. Bozhüyük, A.U.; Kordali, S..; Kesdek, M.; Altınok, M.A.; Varcın, M.; Bozhüyük, M.R. Insecticidal effects of essential oils obtained from six plants against Callosobruchus maculatus (F.) (Coleoptera: Bruchidae), a pest of cowpea (Vigna unguiculata) (L.). Fresenius Environ. Bull. 2016, 25, 2620-2627.

22. Wang, J.; Zhu, F.; Zhou, X.M.; Niu, C.Y.; Lei, C.L. Repellent and fumigant activity of essential oil from Artemisia vulgaris to Tribolium castaneum (Herbst) (Coleoptera: Tenebrionidae). J. Stored Prod. Res. 2006, 42, 339-347. [CrossRef]

23. Negahban, M.; Moharramipour, S.; Sefidkon, F. Chemical composition and insecticidal activity of Artemisia scoparia essential oil against three coleopteran stored product insects. J. Asia-Pac. Entomol. 2006, 9, 381-388. [CrossRef]

24. Negahban, M.; Moharramipour, S.; Sefidkon, F. Fumigant toxicity of essential oil from Artemisia sieberi Besser against three stored-product insects. J. Stored Prod. Res. 2007, 43, 123-128. [CrossRef]

25. Ahmed, M.; Peiwen, Q.; Gu, Z.; Liu, Y.; Sikandar, A.; Hussain, D.; Javeed, A.; Shafi, J.; Iqbal, M.F.; An, R.; et al. Insecticidal activity and biochemical composition of Citrullus colocynthis, Cannabis indica and Artemisia argyi extracts against cabbage aphid (Brevicoryne brassicae L.). Sci. Rep. 2020, 10, 522-532. [CrossRef]

26. Huang, X.; Huang, Y.; Yang, C.; Liu, T.; Liu, X.; Yuan, H. Isolation and insecticidal activity of essential oil from Artemisia lavandulaefolia DC. against Plutella xylostella. Toxins 2021, 13, 842. [CrossRef]

27. Titouhi, F.; Amri, M.; Messaoud, C.; Haouel, S.; Youssfi, S.; Cherif, A.; Jemâa, J.M.B. Protective effects of three Artemisia essential oils against Callosobruchus maculatus and Bruchus rufimanus (Coleoptera: Chrysomelidae) and the extended side-effects on their natural enemies. J. Stored Prod. Res. 2017, 72, 11-20. [CrossRef]

28. Mathela, C.S.; Kharkwal, H.; Shah, G.C. Essential oil composition of some Himalayan Artemisia species. J. Essent. Oil Res. 1994, 6, 345-348. [CrossRef]

29. Bachrouch, O.; Ferjani, N.; Haouel, S.; Jemâa, J.M.B. Major compounds and insecticidal activities of two Tunisian Artemisia essential oils toward two major coleopteran pests. Ind. Crops Prod. 2015, 65, 127-133. [CrossRef]

30. Mohan, M.; Pandey, A.K.; Singh, P.; Nautiyal, M.K.; Gupta, S. Evaluation of Artemisia maritima L. essential oil for its chemical and biological properties against some foodborne pathogens. Anal. Chem. Lett. 2016, 6, 47-54. [CrossRef]

31. Sah, S.; Lohani, H.; Narayan, O.; Bartwal, S.; Chauhan, N.K. Volatile constituents of Artemisia maritima Linn grown in Garhwal Himalaya. J. Essent. Oil-Bearing Plants 2010, 13, 603-606. [CrossRef]

32. Stappen, I.; Wanner, J.; Tabanca, N.; Wedge, D.E.; Ali, A.; Khan, I.A.; Jirovetz, L. Chemical composition and biological effects of Artemisia maritima and Artemisia nilagirica essential oils from wild plants of western Himalaya. Planta Med. 2014, 80, 1079-1087. [PubMed]

33. Chaieb, I.; Ben Hamouda, A.; Tayeb, W.; Zarrad, K.; Bouslema, T.; Laarif, A. The Tunisian Artemisia essential oil for reducing contamination of stored cereals by Tribolium castaneum. Food Technol. Biotechnol. 2018, 56, 247-256. [CrossRef]

34. Liu, C.H.; Mishra, A.K.; Tan, R.X.; Tang, C.; Yang, H.; Shen, Y.F. Repellent and insecticidal activities of essential oils from Artemisia princeps and Cinnamomum camphora and their effect on seed germination of wheat and broad bean. Biores. Technol. 2006, 97, 1969-1973. [CrossRef] [PubMed]

35. Jaitak, V.; Singh, B.; Kaul, V.K. Variability of volatile constituents in Artemisia maritima in western Himalaya. Nat. Prod. Res. 2008, 22, 565-568. [CrossRef]

36. Perry, N.B.; Anderson, R.E.; Brennan, N.J.; Douglas, M.H.; Heaney, A.J.; McGimpsey, J.A.; Smallfield, B.M. Essential oils from Dalmatian sage (Salvia officinalis L.) variations among individuals, plant parts, seasons, and sites. J. Agric. Food Chem. 1999, 47, 2048-2054. [CrossRef]

37. Abou-Taleb, H.K.; Mohamed, M.I.; Shawir, M.S.; Abdelgaleil, S.A. Insecticidal properties of essential oils against Tribolium castaneum (Herbst) and their inhibitory effects on acetylcholinesterase and adenosine triphosphatases. Nat. Prod. Res. 2016, 30, 710-714. [CrossRef] [PubMed] 
38. Zhang, Z.; Guo, S.S.; Zhang, W.J.; Geng, Z.F.; Liang, J.Y.; Dua, S.S.; Wang, C.F.; Deng, Z.W. Essential oil and polyacetylenes from Artemisia ordosica and their bioactivities against Tribolium castaneum Herbst (Coleoptera: Tenebrionidae). Ind. Crops Prod. 2017, 100, 132-137. [CrossRef]

39. Goel, D.; Goel, R.; Singh, V. Composition of the essential oil from the root of Artemisia annua. J. Nat. Med. 2007, 61, 458-461. [CrossRef]

40. Lee, S.E.; Lee, B.H.; Choi, W.S.; Park, B.S.; Kim, J.G.; Campbell, B.C. Fumigant toxicity of volatile natural products from Korean spices and medicinal plants towards the rice weevil, Sitophilus oryzae (L.). Pest Manag. Sci. 2001, 57, 548-553. [CrossRef]

41. Tripathi, A.K.; Prajapati, V.; Aggarwal, K.K.; Kumar, S. Toxicity, feeding deterrence, and effect of activity of 1,8-cineole from Artemisia annua on progeny production of Tribolium castanaeum (Coleoptera: Tenebrionidae). J. Econ. Entomol. 2001, 94, 979-983. [CrossRef]

42. Ogendo, J.O.; Kostyukovsky, M.; Ravid, U.; Matasyoh, J.C.; Deng, A.L.; Omolo, E.O.; Kariuki, S.T.; Shaaya, E. Bioactivity of Ocimum gratissimum L. oil and two of its constituents against five insect pests attacking stored food products. J. Stored Prod. Res. 2008, 44, 328-334. [CrossRef]

43. Shukla, R.; Singh, P.; Prakash, B.; Kumar, A.; Mishra, P.K.; Dubey, N.K. Efficacy of essential oils of Lippia alba (Mill.) N.E. Brown and Callistemon lanceolatus (Sm.) Sweet and their major constituents on mortality, oviposition and feeding behaviour of pulse beetle, Callosobruchus chinensis L. J. Sci. Food Agric. 2011, 91, 2277-2283. [CrossRef] [PubMed]

44. Chiluwal, K.; Kim, J.; Bae, S.D.; Park, C.G. Essential oils from selected wooden species and their major components as repellents and oviposition deterrents of Callosobruchus chinensis (L.). J. Asia Pac. Entomol. 2017, 20, 1447-1453. [CrossRef]

45. Isman, M.B. Plant essential oils for pest and disease management. Crop Prot. 2000, 19, 603-608. [CrossRef]

46. Bakkali, F.; Averbeck, S.; Averbeck, D.; Idaomar, M. Biological effects of essential oils: A review. Food Chem. Toxicol. 2008, 2, 446-475. [CrossRef] [PubMed]

47. Coloma, A.G.; Reina, M.; Diaz, C.E.; Fraga, B.M. Natural product-based biopesticides for insect. In comprehensive natural products II. Chem. Biol. 2010, 3, 237-268.

48. Paolini, J.; El Ouariachi, E.M.; Bouyanzer, A.; Hammouti, B.; Desjobert, J.M.; Costa, J.; Muselli, A. Chemical variability of Artemisia herba-alba Asso essential oils from East Morocco. Chem. Papers 2010, 64, 550-556. [CrossRef]

49. Sharifian, I.; Hashemi, S.M.; Aghali, M.; Alizadeh, M. Insecticidal activity ofessential oil of Artemisia herba alba against three stored product beetles. Biharean Biol. 2012, 6, 90-93.

50. Liu, X.C.; Li, Y.; Wang, T.; Wang, Q.; Liu, Z.L. Chemical composition and insecticidal activity of essential oil of Artemisia frigida Willd (Compositae) against two grain storage insects. Trop. J. Pharm. Res. 2014, 13, 587-592. [CrossRef]

51. Russell, R.J.; Scott, C.; Jackson, C.J.; Pandey, R.; Pandey, G.; Taylor, M.C.; Oakeshott, J.G. The evolution of new enzyme function: Lessons from xenobiotic metabolizing bacteria versus insecticide-resistant insects. Evol. App. 2011, 4, 225-248. [CrossRef]

52. Ramsey, J.S.; Rider, D.S.; Walsh, T.K.; De Vos, M.; Gordon, K.H.J.; Ponnala, L.; Jander, G. Comparative analysis of detoxification enzymes in Acyrthosiphon pisum and Myzus persicae. Insect Mol. Biol. 2010, 19, 155-164. [CrossRef] [PubMed]

53. Li, X.C.; Schuler, M.A.; Berenbaum, M.R. Molecular mechanisms of metabolic resistance to synthetic and natural xenobiotics. Annu. Rev. Entomol. 2007, 52, 231-253. [CrossRef] [PubMed]

54. Yu, S.J.; Hsu, E.L. Induction of detoxification enzymes in phytophagous insects: Role of insecticide synergists, larval age, and species. Arch. Insect Biochem. Physiol. 1993, 24, 21-32. [CrossRef]

55. Bouayad, N.; Rharrabe, K.; Ghailani, N.N.; Jbilou, R.; Domínguez, P.C. Insecticidal effects of Moroccan plant extracts on development, energy reserves and enzymatic activities of Plodia interpunctella. Span. J. Agric. Res. 2013, 11, 189-198. [CrossRef]

56. Clark, A.G.; Shamaan, N.A.; Sinclair, M.D.; Dauterman, W.C. Insecticide metabolism by multiple glutathione S-transferases in two strains of the house fly, Musca domestica (L.). Pestic. Biochem. Physiol. 1986, 25, 169-175. [CrossRef]

57. Hu, Z.D.; Xia, F.E.N.G.; Lin, Q.S.; Chen, H.Y.; Li, Z.Y.; Fei, Y.I.N.; Liang, P.; Gao, X.W. Biochemical mechanism of chlorantraniliprole resistance in the diamondback moth, Plutella xylostella Linnaeus. J. Integr. Agric. 2014, 13, 2452-2459. [CrossRef]

58. Tak, J.H.; Isman, M.B. Metabolism of citral, the major constituent of lemongrass oil, in the cabbage looper, Trichoplusia ni, and effects of enzyme inhibitors on toxicity and metabolism. Pestic. Biochem. Physiol. 2016, 133, 20-25. [CrossRef]

59. Gao, X.W. Insect Adaptation to Plant Allele Chemicals Based on Detoxification: Helicoverpa armigera as an Example; China Agricultural University Press: Beijing, China, 2012.

60. Yang, H.; Piao, X.; Zhang, L.; Song, S.; Xu, Y. Ginsenosides from the stems and leaves of Panax ginseng show antifeedant activity against Plutella xylostella (Linnaeus). Ind. Crops Prod. 2018, 124, 412-417. [CrossRef]

61. Hu, J.; Wang, W.; Dai, J.; Zhu, L. Chemical composition and biological activity against Tribolium castaneum (Coleoptera: Tenebrionidae) of Artemisia brachyloba essential oil. Ind. Crops Prod. 2019, 128, 29-37. [CrossRef]

62. Koundal, R.; Reddy, S.G.E.; Dolma, S.K.; Singh, B. Chemical composition and insecticidal activities of essential oils against diamondback moth, Plutella xylostella (L.) (Lepidoptera: Yponomeutidae). Nat. Prod. Res. 2016, 30, $1834-1838$.

63. Eccles, K.; George, Y.L.P.; Mohammed, F.K.; Khan, A. Efficacy of Artocarpus altilis (Parkinson) Fosberg extracts on contact mortality, repellency, oviposition deterrency and fumigant toxicity of Callosobruchus maculatus (F.) (Coleoptera: Bruchidae). Int. J. Pest Manag. 2019, 65, 72-78. [CrossRef]

64. Nerio, L.S.; Olivero-Verbel, J.; Stashenko, E.E. Repellent activity of essential oils from seven aromatic plants grown in Colombia against Sitophilus zeamais Motschulsky (Coleoptera). J. Stored Prod. Res. 2009, 45, 212-214. [CrossRef] 
65. Kogan, M.; Goeden, R.D. The Host-Plant Range of Lema trilineatadaturaphila (Coleoptera: Chrysomelidae). Ann. Entomol. Soc. Am. 1970, 63, 1175-1180. [CrossRef]

66. Ellman, G.L.; Courtney, K.D.; Andres, V.; Featherstone, R.M. A new and rapid colorimetric determination of acetylcholinesterase activity. Biochem. Pharmacol. 1961, 7, 88-95. [CrossRef]

67. Larson, R.T.; Lorch, J.M.; Pridgeon, J.W.; Becnel, J.J.; Clark, G.G. The biological activity of $\alpha$-Mangostin, a larvicidal botanic mosquito sterol carrier protein-2 inhibitor. J. Med. Entomol. 2010, 47, 249-257. [CrossRef] [PubMed]

68. Bradford, M.M. A rapid and sensitive method for the quantitation of microgram quantities of protein utilizing the principle of protein-dye binding. Anal. Biochem. 1976, 72, 248-254. [CrossRef]

69. Finney, D.J. Probit Analysis, 3rd ed.; Cambridge University Press: Cambridge, UK, 1971. 